\title{
Tuckers firm: a case study of British organised crime
}

James Windle, Senior Lecturer in Criminology and Criminal Justice, University of East London, J.Windle@uel.ac.uk

The final version of the paper as published in the print edition can be found: http://link.springer.com/article/10.1007/s12117-013-9201-9

\begin{abstract}
This article provides a single case study of a British organised crime network operational from the late-1980s to 1996. The network centred around three security firms which spanned the 'spectrum of legitimacy' by legally providing security for licensed venues, whilst taxing and protecting drug dealers, and/or selling drugs in the nightclubs they protected. All three firms employed violence to prevent the encroachment of competitors and extort licensed businesses. Debt collection services were also used as a front for extortion. Actors were individually or collaboratively engaged in: the running of brothels and extortion of sex workers, robbery of drug dealers, burglary, the importation of drugs, and unlawful influence. At least three of the activities (robber, violence and unlawful influence) served a dual purpose: (1) To achieve immediate and tangible goals, such as preventing the encroachment of competing security firms, avoiding prosecution, and material gain; (2) To achieve more distant and abstract goal of creating, maintaining or inflating violent reputations.
\end{abstract}

Keywords Spectrum of legitimacy; Moralistic robbery; Private security; Bouncers; Extortion; Debt collection; Ecstasy; (Auto)biography

\section{Introduction}

This paper adds to the sparse literature of the activities of British organised crime ${ }^{1}$ by detailing a single case study of a network centred on three legitimate security companies

\footnotetext{
${ }^{1}$ The lack of academic contribution is most evident in a review by Wright (2006) of organised crime in the UK. The review relies almost entirely on journalistic sources, with the exception of Dick Hobbs's (1995) London based ethnographic account. This said, Hobbs (2012) recent study on British
} 
Windle, J., 2013. Tuckers firm: a case study of British organised crime. Trends in Organized Crime, 16(4), pp.382-396. Pre-print copy.

interacting with professional criminals working independently, or collaboratively in small groups. The British media have commonly referred to the network as Tuckers Firm or the Essex Boys (henceforth Tuckers Firm or the Firm). ${ }^{2}$

Tuckers Firm operated primarily in Essex and parts of London throughout the late- 1980s until the 1995 murder of three core members: Tony Tucker, Patrick Tate and Craig Rolfe (see Tendler 1997; Thompson 2000). This case study describes the activities of the Firm during the period 1990 to 1995; when Tucker first meets another core member, Carlton Leach, until the dissolution of the network following the triple murder.

While this paper will focus on activities, it is worth briefly noting how Tuckers Firm was structured. The Firm was not a homogenous organisation with a central bureaucracy, leadership and budget. Rather it was a loose network of individuals working around a more stable core (Kenney 2007) connected by their relationship with Tony Tucker (hence Tuckers Firm). Tuckers Firm was, in short, structured like much other British organised crime. It was 'typified by flexibility and unpredictability, operating within multi-layered networks of pecuniary opportunity constituted by both criminal networks and specific activity networks' (Hobbs 2001: 555; see Morselli 2001).

Analysis of the activities of Tuckers Firm lends support for Jay Albanese's (1996: 3) proposal that there may not be an ideal type of organised crime, but rather activities can be placed

organised crime does help fill the void. In addition, while the discussion here focuses on the more working class variation of organised crime (see Hobbs 2012), there has been some work on middle, and upper, class offenders which could come under the organised crime banner (see Ruggiero 2007; Levi 2002; Middleton and Levi 2004).

This article takes as a starting point the definition of an organised crime group provided under international law of a '... structured group of three or more persons, existing for a period of time and acting in concert with the aim of committing one or more serious crimes or offences established in accordance with this Convention, in order to obtain, directly or indirectly, a financial or other material benefit' (UN 2004: Article 2[a]). For an in-depth definitional debate please refer to Jay Albanese (1996) and James Finckenauer (2005).

${ }^{2}$ The Firm attracted widespread media attention after three of its core members were assassinated. Tuckers Firm, and the triple murder, have been the focus of three films (Bonded by Blood; Essex Boys; Rise of the Footsoldier), two of which are based on the (auto)biographies upon which this paper is founded. 
Windle, J., 2013. Tuckers firm: a case study of British organised crime. Trends in Organized Crime, 16(4), pp.382-396. Pre-print copy.

upon a 'spectrum of legitimacy'. The spectrum places more traditional organised criminal activity at one end and legitimate business ventures at the other (see also Smith 1980). This analytical approach avoids the 'black-white dichotomy' which implies 'that an enterprise either is a crime syndicate or a totally legitimate business' (Martin 1981: 56). That is, the legitimacy parameters of activities undertaken by Tuckers Firm were often blurred.

A second finding is that at least three of the activities served dual purposes. Robbery, violence and unlawful influence were used to achieve:

1) Immediate and tangible goals, such as the prevention of disturbances within the club, the encroachment of competing security firms, material gain or the avoidance of prosecution;

2) More distant and abstract goal of creating, maintaining or increasing violent reputations.

Data on the activities of Tuckers Firm was primarily collected from three (auto)biographical accounts written by individuals within, or very close to, the networks inner core: Steve 'Nipper' Ellis (2009), Carlton Leach (2003, 2009) and Bernard O’Mahoney (1997, 2009). The following section discusses the strengths and limitations of relying upon (auto)biographical accounts, and the methods used to overcome some of these limitations. This is followed by a narrative of the activities undertaken by Tuckers Firm.

\section{Data sources and limitations}

Researching organised crime is difficult. Direct observations can be risky, while infiltration of groups or recruitment of willing participants can be complicated. (Auto)biographies use an insider's voice (see Plummer 2001; also Altier et al. 2012) to provide important sources of otherwise unavailable information about professional and organised crime (Morselli 2001, 2003). While (auto)biographies remain underused by criminologists (Morselli 2003), they have been used in a number of studies on organised crime (Albanese 1996; Bovenkerk 2000; Firestone 1993; Morselli 2001, 2003; Hobbs 1995, 2012) and terrorism (Altier et al. 2012; Rapoport 1987; Shapiro and Siegel 2012). The first edition of one of the three sources used in this study (O’Mahoney 1997) has been referenced by Dick Hobbs (2012; Hobbs et al. 2003), Sheridan Morris (1998), and Geoffrey Pearson (2007).

(Auto)biographies as data sources do present unique challenges. The credibility of the data was assessed using criteria developed by John Scott (1990). While it can sometimes feel that the three authors are reiterating official versions of events or local gossip, they were all well 
Windle, J., 2013. Tuckers firm: a case study of British organised crime. Trends in Organized Crime, 16(4), pp.382-396. Pre-print copy.

situated for direct observation. All three authors were part of, or close to, the networks inner core. O’Mahoney and Tucker jointly ran security at a nightclub in Essex between 1993 and 1995; although O'Mahoney appears to have been on the periphery of the Firm's drug distribution enterprises (Ellis 2009; Thompson 2000). Leach had a strong personal relationship with Tucker: they had been close friends and business partners from 1990 until Tuckers death. As such, Leach was considered part of the inner circle (Leach 2003). Ellis was close friends with Tate prior to their involvement with Tuckers Firm, and also appears to have been part of the inner circle from September 1994 (O’Mahoney 2009; Thompson 2000). The relationship between Tuckers Firm and Ellis, however, soon deteriorated. While there are conflicting accounts of the reason for the split all three authors describe how Tucker, Tate and Rolfe engaged in a sustained campaign of psychological and physical abuse against Ellis (Ellis 2009; Leach 2003; see Thompson 2000). Ellis responded with a failed assassination attempt on Tate which left him hospitalised from a gunshot wound (Ellis 2009; see Thompson 2000).

All authors have reason to distort the truth. They may have distorted events to prevent harm to themselves or their acquaintances, or to profit from book sales which depict a more exciting life, whilst downplaying less palatable stories. This is most visibly in all three authors frequent demonization of drug use, which a cynic might suggest is written for more conservative readers.

This said, Ken Plummer (2001) argues that (auto)biographies should not be seen as objective accounts. As individuals perceive events differently, most (auto)biographical work represents partial accounts which may be partially factually inaccurate (see Portelli 1991, cited in Plummer 2001). That is, 'most life story researchers would accept that we can never get at a simple, real truth about a life through a life story' (Plummer 2001: 238).

It is therefore important to investigate alternative sources to validate the author's accounts (Plummer 2001; Scott 1990) and provide supplementary information (Morselli 2003). Validity was checked by comparing events in the three (auto)biographies with each other, and a fourth book written by a journalist (Thompson 2000). Tony Thompson's book was partly based upon interviews with a police informant who had worked with Tuckers Firm (Darren Nichols). The four accounts were also checked against media reports and the findings of academic research. 
Windle, J., 2013. Tuckers firm: a case study of British organised crime. Trends in Organized Crime, 16(4), pp.382-396. Pre-print copy.

While validity checks were mainly positive the accounts conflict in at least two places. Firstly, O’Mahoney was stabbed outside a club in which Leach provided security for. While O'Mahoney claimed to have driven straight home, Leach described O'Mahoney returning to the club, where Leach assaulted O'Mahoney's assailant. The second conflicting account is Ellis's claim that Tucker, Tate and Leach robbed a 'firm' from Canning Town of stolen traveller's check. In Leach's alternative account Ellis (who he calls Willis) was part of the firm selling the travellers checks. Although all agree that Ellis had worked as a broker between Tucker and a friend of his connected to the Canning Town Firm.

While the three (auto)biographies sometimes conflict with each other, together they provide a rare insight into a British organised crime network, from the perspective of key actors. The remainder of this article will describe the range of illicit and licit, and grey area, activities committed individually or collaboratively by members of Tuckers Firm. As legitimate private security represents the conduit linking many activates together, this will be the first area to be discussed.

\section{Private security, drug sales and violence}

In the 1980s and 1990s many British towns and cities actively promoted alcohol based nighttime economies to fill the void left by the decline in British manufacturing (Hobbs et al. 2002, 2003). While policies may have been attributed to 'a genuine desire to encourage urban regeneration' (Roberts 2006: 333), the consequence was that 'mass intoxication, aggression and hedonism' became routine in many city centres after dark (Hobbs et al. 2002: 352). City centres with a high density of licensed venues became the 'hotspot', and weekends became the 'hot time', for violent offending (Wikström 1995). As the state lacked the resources to effectively police the night-time economy (Hobbs et al. 2003), and the police tended to be reactive rather than proactive (Wikström 1995), private security, in the form of doorstaff (colloquially referred to as bouncers), become key crime preventers. That is, the state surrendered and entrusted 'many of its policing duties to bouncers' (Hobbs et al. 2002: 355). The irony is that these agents of crime prevention often became major facilitators of crime, as was the case with security companies connected to Tuckers Firm.

Both Tucker and Leach owned licensed (i.e. legitimate) security companies. They provided security for individuals and licensed venues such as: pubs, restaurants, nightclubs, concerts and sporting events. At their 'peak' they were 'involved in security at many of the top clubs', 
Windle, J., 2013. Tuckers firm: a case study of British organised crime. Trends in Organized Crime, 16(4), pp.382-396. Pre-print copy.

in Essex and London (Leach 2003: 61, 68; Ellis 2009; see Style 1993). While legally separate companies, they were mutually supportive and operated from neighbouring offices (Leach 2003).

O'Mahoney, in partnership with Tucker, ran a smaller security company providing doorstaff for one Essex nightclub (O’Mahoney 2009). O’Mahoney initially partnered with Tucker to exploit his reputation for violence. The objective being that Tuckers name alone would influence 'the behaviour of those who may be likely to cause some kind of trouble' (Winlow 2001: 155). This was an effective strategy, for once the partnership was publicly known:

Trouble makers began to go to other clubs .... Local hardmen who did remain as customers became more friendly and wanted to get in with the firm (O’Mahoney 2009: 43).

While all three businesses were legitimate, they bridged the sphere of legitimacy. The remainder of this section will describe how, to vary extents, they sold, and facilitated the sale of, illicit drugs. They also used violence and intimidation to prevent the encroachment of competing security companies and maintain security within the venues they were paid to protect. The following discussion should not be taken as suggesting that all doorstaff employed by Leach, O'Mahoney and Tucker were engaged in illicit activities. Previous research into the 1990s security industry suggests that direct involvement in drug sales was limited to a minority of doorstaff (Morris 1998; Hobbs et al. 2003). This said, many doorstaff directly uninvolved in drug sales facilitated distribution and consumption turning a blind eye (see also Sanders 2005).

Research conducted during the 1990s on drug dealing in licensed venues identified links between doorstaff and the sale of illicit drugs, and/or facilitation of drug sales (see Hobbs 1995; Hobbs et al. 2003; Measham et al. 2001; Morris 1998; Sanders 2005; Ward 2010), and other commodities (Winlow 2001). At least one of Tuckers doorstaff, described as a 'prominent member' of Tuckers Firm by Ellis, sold drugs in a club where Tucker managed security (Ellis 2009: 164; also O’Mahoney 2009). O’Mahoney (1997: 83), moreover, claimed that Tucker 'employed' dealers. Tucker, Leach and O'Mahoney also taxed dealers who sold drugs in the venues they provided security for. Leach (2003: 25) notes how: 
Windle, J., 2013. Tuckers firm: a case study of British organised crime. Trends in Organized Crime, 16(4), pp.382-396. Pre-print copy.

By controlling club doors we could control who was running the drugs inside and we made dealers cough up $£ 1,000$ a time to operate in the top places (see also O'Mahoney 2009; also Thompson 2000). ${ }^{3}$

After paying the tax the doorstaff prevented competing drug dealers from entering the nightclub and alerted approved dealers to police presence (O’Mahoney 2009). Leach (2003: 56) recalls how:

...the whole firm, had all gone up to Suffolk by car to sort out a problem at one of the clubs where Tony [Tucker] handled the security where some local dealers were serving up [selling] drugs which were not "approved" by Tony. The manager asked Tony to get up a heavy team to sort it. We got up two car loads, about eight of us altogether..., and we planned to arrive by surprise, lock up the back doors of the club and trap the dealers inside.

An important element of this quote is how the nightclubs manager requested Tuckers support in removing the non-approved dealer. Similarly, the manager of a major London club asked Leach to remove dealers as the nightclub had 'a couple of our own people' selling drugs (Leach 2003: 80). The manager did not initially offer Leach any additional incentive, so he extorted the manager by ejecting all dealers:

This place was drug dry. And the night was dead//The next night I was called in by one of the anxious bosses.... asking What's going on? What are you up to?// From that day on, I got a tasty bonus every week for allowing only management-approved dealers to operate in the club. I'm sure the owners didn't know what was happening, but certain key members of staff were involved in a massive drugs ring serving up [ecstasy] pills... (Leach 2003: 82).

O'Mahoney, similarly, stated in Norwich Crown Court that the owner of the nightclub he provided security for permitted drug dealing (Horsnell 1996; Independent 1996; also Watkins 1996).

\footnotetext{
${ }^{3}$ Hobbs and colleagues (2003: 111) were similarly told by doorstaff they interviewed: 'If you've got control of the door you can sell your drugs'.
} 
Windle, J., 2013. Tuckers firm: a case study of British organised crime. Trends in Organized Crime, 16(4), pp.382-396. Pre-print copy.

The consumption of certain illicit drugs was central to the atmosphere of the dance clubs and illegal raves of the 1980s/1990s (Hobbs et al. 2003;Ward 2010). Leach and O'Mahoney's accounts validate the findings of ethnographic studies which suggested that, as some venues were dependent upon drugs for financial success, 'management systems were complicit in the existence of drugs trade and supply on their premises' (Ward 2010: 156; also Sanders 2005). In some respects, such nightclubs became open drug markets (Ward 2010). Although as customers often had to be proactive in finding concealed dealers, the market was seldom overt (Measham et al. 2001). ${ }^{4}$

O'Mahoney (2009) describes how drug dealing was organised in the nightclub he managed security for. Dealer managers paid the doorstaff a fee in exchange for the protection of their floor dealers. The dealer managers paid people to store drugs which were given to couriers who delivered to floor dealers operating in various clubs. One courier, for example, was arrested with 100 ecstasy tablets and told the police he had made eight deliveries that evening to a variety of clubs across London. The floor dealers would then sell the drugs under the supervision and management of the dealer managers, and protection of door staff. Floor dealers kept a percentage of everything they sold. This account is consistent with the description given by Sheridan Morris (1998). O’Mahoney (1997) claimed that dealer managers had to buy all of their drugs from Tucker. It is, however, unclear whether Tucker maintained, or attempted to maintain, a monopoly on distribution as O'Mahoney later described how one group of dealers brought weaker ecstasy tablets from elsewhere (O’Mahoney 2009).

To prevent other dealers selling in their clubs, the doorstaff would:

... recruit people who weren't actually willing to sell drugs. They would be told: "Here's twenty pounds, you go into the club and see if you can buy ecstasy or any other drug off anyone. As soon as you find someone selling, buy it off them, come back to us and point them out; we'll take them to the fire exit, spin them, take all their money and take all their drugs" .../... Our

\footnotetext{
${ }^{4}$ In the nightclub protected by O'Mahoney drugs were procured from social networks (Independent 1996) as well as security facilitated floor sales. As several studies have found that the majority of consumers at dance events acquire drugs from social networks, it is likely that floor sales represented a minor source of drugs (Forsyth 1996; Measham et al. 2001; Parker 2000).
} 
Windle, J., 2013. Tuckers firm: a case study of British organised crime. Trends in Organized Crime, 16(4), pp.382-396. Pre-print copy.

firm took half and the other half went to our recruit for his personal use. Either that or we paid him the money. Those drugs would more than likely be sold back to the firm's dealers who would benefit because a rival would have been taken out of the game. That was the way ... most other clubs kept them [rival dealers] out of [their nightclubs] (O’Mahoney 2009: 158/9; see Hobbs et al. 2003 for a description of a similar process employed in Manchester).

In one example, Ellis witnessed Tucker at a rave:

As soon as he spotted a drug dealer not on his payroll Tucker grabbed him by the throat, slapped his face, stole his cash and drugs ... I am aware of at least four drug dealers he robbed in a similar manner that day (Ellis 2009: $55)$.

As well as facilitating drug dealing, a police statement following the death of Tucker, Tate and Rolfe described how they sold a variety of drugs 'wholesale rather than retail' (Bennett 1995: 4). Leach (2003: 183) refers to Tucker as a 'major drug-dealer' and Ellis witnessed Tucker distributing packets of Ecstasy pills to floor dealers at an illegal rave (Ellis 2009). ${ }^{5}$ Tucker also employed couriers to distribute drugs (O'Mahoney 2009), although it is unclear whether this was to sub-contracted floor dealers or to dealer managers, who then subcontracted to their own floor dealers.

Tucker, Tate and Rolfe would pool their money to procure large quantities of illicit drug from importers (Tendler 1997). In one case Tate, Tucker, Rolfe and a consortium of investors financed the importation of $£ 55,000$ worth of cannabis (Ellis 2009; also Thompson 2000). ${ }^{6}$ The investors were 'shady car dealers, villains and dodgy businessmen' (O’Mahoney 2009: 151; see Smith 2000); including the members of the smuggling crew who were importing the drugs (Thompson 2000; see Tendler 1997). ${ }^{7}$

\footnotetext{
${ }^{5}$ Tucker also owned a health-food shop in Ilford where he sold steroids illegally to bodybuilders, alongside sports equipment and health food (Leach 2003).

${ }^{6}$ Smith (2000) describes how money was also pooled for the importation of ecstasy.

${ }^{7}$ Tate's brother Russell was jailed in 1998 for five years for conspiring to import $£ 500,000$ of cannabis alongside the smuggling crew Tate had brought drugs from (Ilyas 1998; also Thompson 2000).
} 
Windle, J., 2013. Tuckers firm: a case study of British organised crime. Trends in Organized Crime, 16(4), pp.382-396. Pre-print copy.

Once in the country, the drugs were divided between the investors. Shares were depended upon the amount originally invested. Rolfe, for example, sold his share of imported cannabis to a North London drug dealer, while one of the smugglers (Nicholls) sold his share in smaller packages to dealers in Cambridge, Essex and London (Thompson 2000).

Another illicit activity connected to security was the use of violence to prevent the encroachment of competitors and prevent disturbances within the venue they were protecting. For example, when Leach first took over security at a major London club he feared a conflict with a rival security firm. Leach went to work with 'a bag of tools [weapons] ..., a couple of knives, some coshes, baseball bats'. There was a standoff when the rival firm turned up at the club. Leach and his doorstaff had 'agreed, whoever came at us first, we'd chook them up [cut them with a knife]'. Winning the standoff was perceived as 'an important victory for us in reinforcing our authority' (Leach 2003: 79).

O’Mahoney (2009: 113) similarly recalls how he was attacked when he tried to eject two rivals:

It was hard to say exactly what happened. I was trying to get people out of the building and defend myself at the same time..... Somebody was holding on to my back and a man was trying to get up off the floor. I began to stamp on him. We were outnumbered. I produced a knife, and our attackers started to back off.

One of the rivals was left 'lying on the floor unconscious, his face a mass of blood' (O’Mahoney 2009: 113).

There are also several examples of customers being assaulted, beyond the 'reasonable force' permitted under section 3(1) of the Criminal Law Act 1967. O’Mahoney (2009) describes how he: hit one customer with a fire extinguisher, cut another with a knife in the face and thigh, and beat a third so badly that he stopped breathing for a short time. In the most extreme example, O'Mahoney assaulted a customer for mocking him. The man returned and petrol bombed the clubs entrance. O'Mahoney retaliated by knocking the assailant unconscious before dousing him in petrol, because '[y]ou couldn't allow people to take liberties like that' (O’Mahoney 2009: 146).

Leach provides two further examples. In the first, a disgruntled customer was thrown out of a boat party by Leach. When he returned with a gun, Leech and his doorstaff: 
Windle, J., 2013. Tuckers firm: a case study of British organised crime. Trends in Organized Crime, 16(4), pp.382-396. Pre-print copy.

... dragged him down an alleyway nearby ... [where] he received a savage beating, more than $20 \mathrm{stab}$ wounds, and was as close to death as is possible to be while still breathing...//... half his stomach was hanging out. And he'd been beaten to a pulp with knuckledusters and baseball bats (Leach 2003: 9).

In the second example, when an assailant attempted to stab one of Leach's doorstaff he hit him about the head with an 'iron bar covered in a bit of rubber' (Leach 2003: 44). Leach justifies the brutality of his actions by firstly demonizing drugs ('[i]t was at a time when I was doing steroids big time, doing all sorts of drugs') and then declaring that: '[i]n that world, respect is all important and he had shown total disrespect' (Leach 2003: 46).

Both Leach and O'Mahoney's accounts imply that violence was necessary to control a licensed venue, and for the safety of customers. O'Mahoney (2009: 40) argues in defence of the utility of violence:

Prior to my arrival at [the nightclub] ... people had taken liberties all the time. By using excessive violence to combat violence, I had reduced the amount of trouble, and people were thinking twice about starting anything in the club ...//... On the surface the revellers were beginning to see a decrease in violence...

While a certain level of violence may have been necessary to prevent staff and customers from being injured, a number of studies have found that aggressive doorstaff promote aggression (Roberts 2008; see Homel and Clark 1994; Homel et al. 1992; Winlow 2001). As such, a reduction in aggression may have been more effectively, and legally, reduced by designing out opportunities for conflict and provocation (see Graham and Homel 2008).

Both Leach and O'Mahoney suggest that 'respect' was established by developing the firm's violent reputation (see Hobbs 1995; Winlow 2001). As signs of perceived weakness may be seen as an invitation to competitors (Winlow 2001) the development of a violent reputation may be more instrumental in reducing the encroachment of competing security and drug dealing firms (see Bourgois 1995; Sanders 2005) than preventing disturbances. That is, as in legitimate businesses, 'a good reputation attracts customers and keeps competitors at bay' (Gambetta 1993: 44). 
Windle, J., 2013. Tuckers firm: a case study of British organised crime. Trends in Organized Crime, 16(4), pp.382-396. Pre-print copy.

It is not the author's intention to demonise doorstaff. They often work in insecure and hostile environments, and mostly deal with violence without recourse to excessive force (Hobbs et al. 2003; Monaghan 2004). Rather this section has shown how some employees of Tucker, Leach and O'Mahoney's security firms used excessive force to secure their authority inside the venues they were paid to protect and, possibly more importantly, to develop a reputation of violence designed to warn off competitors.

\section{Debt collection/extortion}

Another area which spanned the sphere of legitimacy was debt collection. O'Mahoney (2009: 56) describes how '[b]ecause of the firm's reputation' for violence they began collecting debts (see Thompson 2000). Debt collection was also used, by some, as a front for extortion. O'Mahoney recalls how they would tell potential clients that there was no upfront fee, but a third of the collected debt would be kept. The signed contract would specify that:

... we would remain with it [the debt] until the money was recovered; the person who employed us couldn't change his mind or if he did, he had to pay us a third of the debt as our fee.//What we used to do, however, was intimidate the person owing the money, or cause a scene at his home so he would call the police. The police, knowing who we were, would go to the person the money was owed to and tell them that if there were any more problems, they would be prosecuted (O’Mahoney 2009: 58).

When the client asked for the contract to be cancelled they would be told that:

... if they pulled out, they would have to pay us a third. Fearing prosecution from the police on one side, and violence from us on the other, they had no choice but to pay (O’Mahoney 2009: 58).

For example, O’Mahoney was employed to track down a debt of $£ 60,000$ :

We descended on [the client] ... after a bit of intimidation he agreed to pay us $£ 3,000$ expenses to fly to Geneva to try and apprehend the man who was holding his money. We took [the clients] ... cash but never went as far as the end of Southend Pier (O'Mahoney 2009: 58). 
Windle, J., 2013. Tuckers firm: a case study of British organised crime. Trends in Organized Crime, 16(4), pp.382-396. Pre-print copy.

After losing the security contract for a major London nightclub, Leach also established a debt collection service with three friends, one of whom held a debt-collectors license. Leach's methods were more legitimate than O'Mahoney's:

We'd never turn up mob-handed on someone's doorstep ...//We never raise our voices. We sit and talk. That does people. Gary does most of the talking ... I sit right beside him looking sinister. Another heavy will sit a few feet away just staring at the bloke. It's enough to make anyone shit themselves. It works ... I'm not saying we wouldn't get a bit noisier, a bit heavier, if someone didn't cough up. But that hasn't happened yet (Leach 2003: 97).

This said, Leach later describes how he collected a $£ 50,000$ debt for a friend by pretending to have a gun and then hitting the debtor with 'backhand right across his face'. An acquaintance of Leach's then hit the debtor again before Leach told him '[i]f you haven't got the money in ten minutes ... we'll put you through the glass doors' (Leach 2003: 242). In another example, Leach and a 'hand-picked team' stole a number of cars from a used car dealer who owed a friend of Leach’s 225,000 (Leach 2003: 145).

\section{Extortion}

While one journalist linked Tuckers Firm to extortion (Freeman 1999), none of the authors claim to have extorted legitimate businesses. There are, however, a number of examples of members of Tuckers Firm unlawfully obtaining money through violent or non-violent coercion (Hobbs 2010).

There is one example of O'Mahoney threatening the owner of a venue unwilling to contract out security to Tucker and his security firm. O’Mahoney (2009) recalls how he and Tucker entered into a verbal contract with the licensed venue to provide security. After the contract was given to a rival security firm O'Mahoney and one of his doorstaff:

... went [to the venue] ... to have a drink. There were disturbances, and the security ran off and telephoned the police. Large numbers of officers turned up and insisted that the other doormen and I, who were in there having a quiet drink, should leave at once (O’Mahoney 2009: 53).

When Basildon council threatened to revoke O'Mahoney's door license after this incident, O'Mahoney responded 'other firms couldn't ... undercut you and take your door and expect 
Windle, J., 2013. Tuckers firm: a case study of British organised crime. Trends in Organized Crime, 16(4), pp.382-396. Pre-print copy.

nothing to happen' (O’Mahoney 2009: 55). While O'Mahoney deciding to drink in the venue whilst a fight occurred may have been a coincidence, it is common practice for extortionists to cause disturbances to coerce businesses to conform to their demands (see Hobbs et al. 2003; Morris 1998; Winlow 2001). Furthermore, that O'Mahoney did not openly threaten the venue does not absolve him from extortion. For example, in Northern Ireland, Loyalist paramilitaries often asked businesses for donations in a manner which made the victim feel 'menaced' (Silke 2000: 340).

Tuckers Firm's activities ranged the sphere of legitimacy, and so too did its extortion targets. Aside from O'Mahoney's debt collection customers and licensed venues, the Firm also extorted sex workers and drug dealers. Tate, for example, would coerce sex workers to work for him in an Essex brothel (Ellis 2009; see O’Mahoney 2009). While the taxation of drug dealers operating in clubs they provided security for is in essence extortion of 'the main productive activities carried out within their territory' (Paoli 2004: 22). Such authority was, however, limited. Contrary to Leach's (2003: 25) declaration that 'we'd been ruling Essex like we owned the fucking place', extortion never extended beyond a few licensed venues and individuals. That is, extortion never reached the extent witnessed in some areas of Northern Ireland (Silke 2000) or Southern Italy (Paoli and Fijnaut 2006).

Although, like Northern Irish and Southern Italian extortion, the "violence of extortion and the self-interest of the "victim" tends to merge and to provide an inextricable set of reasons for cooperation' (Gambetta 1990: 170). Extorted drug dealers and sex workers were provided with protection unavailable from the state (see Albanese 1996), while some extorted licensed venues may have been content to pay the fee in exchange for the protection of a 'face', especially in the absence of effective state presence.

\section{Protection for other criminal enterprises}

Leach and O'Mahoney also provided protection for individuals or groups involved in other illicit (or quasi-illicit) activities. Leach, for example, ran security for illegal raves during the late-1980s and early-1990s (Leach 2003). ${ }^{8}$ He was also paid to protect the transit of $£ 250,000$

\footnotetext{
${ }^{8}$ Leach (2003) had been a member of the West Ham Inter-City football hooligan firm. During the 1980s/early-1990s, several former football hooligans, like Leach, exploited the emergence of illegal raves by offering their services as security, before moving into the provision of security for licensed
} 
Windle, J., 2013. Tuckers firm: a case study of British organised crime. Trends in Organized Crime, 16(4), pp.382-396. Pre-print copy.

destined for Amsterdam (Leach 2003) while two drug dealer managers paid O'Mahoney (2009) to protect them during drug deals and prevent extortion from other security firms (O’Mahoney 1997).

\section{Robbery}

Robbery is a common theme in Ellis's account. He was part of a small network of petty professional burglars, loosely connected to Tuckers Firm, who would sometimes fence stolen goods to members of the Firm (Ellis 2009). Drawing parallels with Leach's displacement from security to debt collection, technological innovation and market demand forced Ellis and his network to slowly replaced burglary with drug dealing (Ellis 2009; see Dorn et al. 1992; Hobbs 1995, 2012; for a critical analysis of displacement theory see Windle and Farrell 2012). Aside from Ellis, Tate was involved in the robbery of jewellery shops (Ellis 2009; also Thompson 2000).

Several members of Tuckers Firm were involved in one of 'criminology's dirty little secrets': that a large amount of crime takes place against criminals (Topalli et al. 2002: 337; see Wright et al. 2006). Tuckers Firm were 'supposed to be into robbing other villains in a big way' (Leach 2003: 75; also Ellis 2009; Thompson 2000). For example, Tate and Ellis robbed a drug dealer of $80 \mathrm{~kg}$ of cannabis and $£ 50,000$ of cash. During the robbery Tate beat one of the men until '[b]lood splashed the walls' (Ellis 2009: 36). There are other accounts of Tucker pretending to have been raided by the police midway through a deal so that he did not have to pay for the 'seized' drugs (O’Mahoney 2009; Thompson 2000; for a discussion on how the robbery of drug dealers increased during the 1990s see Hobbs 2012).

According to Leach (although disputed by Ellis and O'Mahoney) Ellis was part of firm of professional criminals selling stolen travellers checks, which Tucker wanted to buy. After Ellis failed to show up to five meetings, Tucker, Tate and Rolfe burgled Ellis's flat and stole his car before subjecting him to a series of physical and psychological assaults (Ellis 2009; see Leach 2003). In another example a sex worker who paid Tate for protection was robbed by a client. Tate and Ellis broke into the client's house and, beat and robbed him (Ellis 2009). Robbery to right a perceived wrong falls under what Bruce Jacobs and Richard Wright (2008) term 'moralistic robbery'. The two robberies communicated that Tuckers Firm would not

venues: successfully manoeuvring themselves from 'violent entrepreneurial delinquency' into ‘independent, working-class businessmen’ (Hobbs 2012: 120; see Pritchard and Parker 2011). 
Windle, J., 2013. Tuckers firm: a case study of British organised crime. Trends in Organized Crime, 16(4), pp.382-396. Pre-print copy.

suffer perceived disrespect, helped maintain their reputation whilst providing retaliation and material restitution (see also Wright et al. 2006). ${ }^{9}$ In short, like violence against competitors and aggressive club customers, robbery was used to build a violent reputation which could deter other criminals.

\section{Fraud and counterfeit currency}

While fraud was not a major theme explored by the three authors, there were several cases. These ranged from O'Mahoney (2009) providing an underage doorman with a fake birth certificate to credit card fraud. Tate, for example, used credit cards stolen by a friend from a Royal Mail sorting office (Ellis 2009). While Tucker staged a burglary of his health food shop, took all the stock and filed for bankruptcy (Ellis 2009). His security company would also provide Leach and O'Mahoney with invoices to allow them to pay their employees cash and thus avoid paying tax (Leach 2003; O’Mahoney 2009; see Morris 1998).

Ellis recalls how he and Tate procured and spent counterfeit currency. They would buy $£ 50$ notes for $£ 12.50$ and either buy drinks in nightclubs to collect the change, or buy goods in chain stores. They would then take the goods back to the same store in a different town to receive a refund (Ellis 2009). Additionally, Nicholls, one of the smugglers who worked for Tate was sentenced in 1992 to eight months imprisonment for the distribution of counterfeit currency (Thompson 2000).

\section{Unlawful influence}

Unlawful influence is one of the central characteristics of organised crime. It is defined as using 'harassment (subtle, not punishable acts), threats, violence, malicious damage and corruption..., where the aim is to influence someone to act or refrain from acting'. There is an obvious utility to using violence and intimidation to unlawfully influence witnesses and victims. A less obvious use, however, is to inflate the group or individuals reputation (Korsell and Skinnari 2010: 154).

\footnotetext{
${ }^{9}$ This is not to say that such violence was purely instrumental. As Hobbs (2012) reminds us, the boundaries between 'personal and commercial violence' are often blurred. This is apparent with the abuse levelled at Ellis which, while used to secure and maintain their reputation, is described by Ellis, Leach and O'Mahoney as distinctly personal: Ellis 'had become an obsession with Tony.... Tony, Pat and Craig were hell-bent on making Willis [Ellis] suffer for the bodged-up travellers ' cheques' (Leach 2003: 163).
} 
Windle, J., 2013. Tuckers firm: a case study of British organised crime. Trends in Organized Crime, 16(4), pp.382-396. Pre-print copy.

O’Mahoney (2009) provides a number of accounts of members of Tuckers Firm intimidating victims to prevent them from pressing charges. For example, O’Mahoney (2009: 43) knocked a man unconscious for making 'a few silly remarks' about his doorstaff. The victim reported the assault to the police but he was:

Spotted in a pub in Basildon by amutual friend, and he suddenly remembered that it was entirely his fault and the case against me was dropped (O’Mahoney 2009: 43).

In another example, a drug dealer protected by O'Mahoney shot a man who had robbed his home. O’Mahoney offered the victim of the shooting $£ 20,000$ to drop charges against the drug dealer and retract his statement. When the victim asked for half the money up front O’Mahoney drove him to a disserted lane and put a gun to his head (O'Mahoney 2009). Similarly, Ellis and Tate intimidated a victim of assault and robbery who was pressing charges against them (Ellis 2009). While in the most extreme example a man threatening to provide evidence against Tucker in an assault case had his (empty) car shot with a machine gun (Thompson 2000).

\section{Conclusion}

This paper has used a single case study to provide some insight into British organised crime during the 1990s. The single case study supports previous research into the linkages between organised crime and doorstaff whilst going further than other accounts by investigating other illicit activities undertaken by the professional criminals who ran legitimate private security firms.

The activities of Tuckers Firm spanned the spectrum of legitimacy. That is, members of Tuckers Firm used illegitimate means to further profits of legitimate businesses they owned, or worked for, whilst also making profit from purely illegal activity unconnected to legitimate business. Several activities, especially debt collection clustered 'at the margin of legitimacy' (Smith 1980: 382).

It is also apparent from the three (auto)biographical narratives that several activities possessed a dual function, especially robber, violence and unlawful influence. These activities were used to achieve immediate and tangible goals, such as material gain, the avoidance of prosecution, the prevention of disturbances within 'their' nightclubs and the encroachment of competing security firms. Such activities were additionally used to achieve 
Windle, J., 2013. Tuckers firm: a case study of British organised crime. Trends in Organized Crime, 16(4), pp.382-396. Pre-print copy.

more distant, and abstract, goals of creating, maintaining or increasing the violent reputations upon which successful criminal enterprises are founded.

\section{Acknowledgement}

The author would like to thanks John Blake Publishing and Mainstream Publishing for providing permission to use the three autobiographies, Bernard O'Mahoney for taking the time to discuss the paper, and the reviewers for their helpful comments.

\section{References}

Albanese J (1996) Organized crime in America. Anderson Publishing, Cincinnati Altier MB, John H, Thoroughgood C (2012) In their own words? methodological considerations in the analysis of terrorist autobiographies. J Strateg Secur 5(4):85-98

Bennett W (1995) Double-cross theory on murder of drug dealers. The Independent, 9 December

Bourgois P (1995) In search of respect: selling crack in El Barrio. Cambridge University Press, Cambridge

Bovenkerk F (2000) "Wanted mafia boss" - essay on the personology of organized crime. Crime Law Soc Chang 33(3):225-242

Dorn N, Murji K, South N (1992) Traffickers. Routledge, London

Ellis S (with O’Mahoney B) (2009) Essex boy: Last man standing. Mainstream, Edinburgh Finckenauer JO (2005) Problems of definition: what is organized crime? Trends Organized Crime 8(3):63-83

Firestone TA (1993) Mafia memoirs: what they tell us about organized crime. J Contemp Crim Law 9(3):197-220

Forsyth A (1996) Are raves drug supermarkets? Int J Drug Policy 7(2):193-209

Freeman C (1999) Mystery grows as "aid worker" flees Congo jail shootout. Evening Standard, 8 January

Gambetta D (1990) Mafia: the price of distrust. In: Gambetta D (ed) Trust: making and breaking cooperative relations. Blackwell, Oxford 
Windle, J., 2013. Tuckers firm: a case study of British organised crime. Trends in Organized Crime, 16(4), pp.382-396. Pre-print copy.

Gambetta D (1993) The Sicilian Mafia. Harvard University Press, London

Graham K, Homel R (2008) Raising the bar: preventing aggression in and around bars, pubs and clubs. Willan Publishing, Devon

Hobbs D (1995) Bad business: professional crime in modern Britain. Oxford University Press, Oxford

Hobbs D (2001) The firm: organisational logic and criminal culture on a shifting terrain. $\mathrm{Br}$ J Criminol 41(4):549-560

Hobbs D (2010) Extortion. In: Brookman F, Maquire M, Pierpoint H, Bennet T (eds) Handbook on crime. Willan, London

Hobbs D (2012) Lush life: constructing organised crime in the UK. Oxford University Press, Oxford

Hobbs D, Hadfield P, Lister S, Winlow S (2002) 'Door lore': the art and economics of intimidation. Br J Criminol 42(3):352-370

Hobbs D, Hadfield P, Lister S, Winlow S (2003) Bouncers: violence and governance in the night-time economy. Oxford University Press, Oxford

Homel R, Clark J (1994) The prediction and prevention of violence in pubs and clubs. In: Clarke R (ed) Crime prevention studies. Criminal Justice Press, New York Homel R, Tomsen S, Thommeny J (1992) Public drinking and violence: Not just an alcohol problem. J Drug Issues 2(22):679-697

Horsnell M (1996) Murdered drugs dealer linked to Leah Betts death. The Times, 12 December

Ilyas M (1998) Easy money on drugs costs friends 30 months. Birmingham Post, 31 October Independent (1996) Club doorman names Leah's ecstasy dealer. The Independent, 12 December

Jacobs BA, Wright R (2008) Moralistic street robbery. Crime and Delinquency 54(4):511531

Kenney M (2007) From Pablo to Osama: trafficking and terrorist networks, government bureaucracies, and competitive advantage. Penn State University Press, Pennsylvania 
Windle, J., 2013. Tuckers firm: a case study of British organised crime. Trends in Organized Crime, 16(4), pp.382-396. Pre-print copy.

Korsell L, Skinnari J (2010) Situational crime prevention against unlawful influence from organised crime. In: Bullock K, Clarke RV, Tilley N (eds) Situational crime prevention of organised crime. Willan Publishing, London

Leach C (2003) Muscle. Blake, London

Leach C (2009) Rise of the footsoldier. Blake, London

Levi M (2002) The organization of serious crime. In: Maquire M, Morgan R, Reiner R (eds) The Oxford handbook of criminology. Oxford University Press, Oxford

Martin WA (1981) Toward specifying a spectrum-based theory of enterprise. Crim Justice Rev 6(1):54-57

Measham F, Aldridge J, Parker H (2001) Dancing on drugs: risk, health and hedonism in the British club scene. Free Association Press, London

Middleton DJ, Levi M (2004) The role of solicitors in facilitating 'organized Crime': situational crime opportunities and their regulation. Crime Law Soc Chang 42:123-161

Monaghan LF (2004) Door work and legal risk: observations from an embodied ethnographer. Soc and Legal Stud 13(4):453-480

Morris S (1998) Clubs, drugs and doormen. Crime detection and prevention series, Paper 86. London, Home Office Police Research Group.

Morselli C (2001) Structuring Mr. Nice: entrepreneurial opportunities and brokerage positioning in the cannabis trade. Crime Law Soc Chang 35(3):203-244

Morselli C (2003) Career opportunities and network-based privileges in the Cosa Nostra. Crime Law Soc Chang 39(4):383-418

O’Mahoney B (1997) So this is ecstasy. Mainstream, Edinburgh

O’Mahoney B (2009) Essex boys: a terrifying expose of the British drug scene. Mainstream, Edinburgh

Paoli L (2004) Italian organised crime: mafia associations and criminal enterprises. Global Crime 6(1):19-31

Paoli L, Fijnaut C (2006) Organised crime and its control policies. Eur J of Crime, Crim Law and Crim Justice 14(3):307-327 
Windle, J., 2013. Tuckers firm: a case study of British organised crime. Trends in Organized Crime, 16(4), pp.382-396. Pre-print copy.

Parker H (2000) How young Britain's obtain their drugs: drugs transactions at the point of consumption. In: Natarajan M, Hough M (eds) Illegal drug markets: from research to prevention. Crime prevention studies. Criminal Justice Press, New York

Pearson G (2007) Drug markets and dealing: from "street dealer" to "Mr Big”. In: Simpson M, Shildrick T, McDonald R (eds) Drugs in Britain: supply, consumption and control. Palgrave Macmillan, London

Plummer K (2001) Documents of life 2: an invitation to a critical humanism. Sage, London Pritchard A, Parker N (2011) Urban smuggler. Mainstream, Edinburgh

Rapoport D (1987) The international world as some terrorists have seen it: a look at a century of memoirs. In: Rapoport D (ed) Inside terrorist organizations. Frank Cass, London RobertsM (2006) From 'creative city' to 'no-go areas' - the expansion of the night-time economy in British towns and city centres. Cities 23(5):331-338

Roberts JC (2008) Bouncers and barroom aggression: a review of the research. Aggress Violent Behav 14:59-68

Ruggiero V (2007) It's the economy, stupid! classifying power crime. Int J Soc Law 35(4):163-177

Sanders B (2005) In the club: ecstasy use and supply in a London nightclub. Sociology 39(2):241-258

Scott J (1990) A matter of record. Polity Press, Oxford

Shapiro JN, Siegel DA (2012) Moral hazard, discipline, and the management of terrorist organizations. World Politics 64:39-78

Silke A (2000) Drink, drugs, and rock'n'roll: Financing loyalist terrorism in Northern Ireland — part two. Stud Confl Terrorism 23(2):107-127

Smith DC (1980) Paragons, pariahs, and pirates: a spectrum-based theory of enterprise.

Crime Delinq 26:358

Smith A (2000) From sweet shop thief to a feared cop killer. Daily Record 15 April Style J (1993) Yeah, minister; The battle for supremacy rages in clubland. The Independent 17 November 
Windle, J., 2013. Tuckers firm: a case study of British organised crime. Trends in Organized Crime, 16(4), pp.382-396. Pre-print copy.

Tendler S (1997) Drug men "lured into gun ambush". The Times 3 September

Thompson T (2000) Bloggs 19: the story of the Essex range rover triple murders. Warner, London

Topalli V, Fornango R, Wright R (2002) Drug dealers, robbery, and retaliation: vulnerability, deterrence, and the contagion of violence. Br J Criminol 42:337-351

UN (United Nations) (2004) United Nations convention against transnational organised crime. UNODC, Vienna

Ward JR (2010) Flashback: drugs and dealing in the golden age of the London rave scene. Willan, Devon

Watkins A (1996) Retrial ordered in Leah Betts case. The Guardian 21 December Wikström PH (1995) City-centre street crimes. Crime Justice 19:429-468

Windle J, Farrell G (2012) Popping the balloon effect: assessing drug law enforcement in terms of displacement, diffusion and the containment hypothesis. Subst Use Misuse 47(8/9):868-876

Winlow S (2001) Badfellas: crime, tradition and new masculinities. Berg, Oxford Wright A (2006) Organised crime. Willan, London

Wright R, Brookman F, Bennett T (2006) The foreground dynamics of street robbery in Britain. Br J Criminol 46:1-15 